\title{
From Gagarin to Sputnik: the role of nostalgia in Russian public diplomacy
}

\author{
Ilan Manor ${ }^{1} \cdot$ James Pamment ${ }^{2}$
}

Accepted: 20 September 2021 / Published online: 26 October 2021

(c) The Author(s), under exclusive licence to Springer Nature Limited 2021

In recent years, diplomats have increasingly employed nostalgic tropes in their digital communications (Surowiec and Manor 2020). As a public diplomacy instrument, nostalgia serves two ends. First, nostalgia can be used to help digital public makes sense of complex crises using historical precedent. Second, nostalgia can be used to reduce feelings of uncertainty brought about by globalization and the contestation of local traditions as well as novel planetary threats. By summoning a nation's past to the present, the past becomes a template that illuminates the present and elucidates the future (Miskimmon et al. 2014). For instance, British officials have equated Brexit with the British Empire's 'last stand' during WWII in which an independent UK charted its own destiny (Saunders 2020).

Over the past 2 years, the Russian MFA has promoted three nostalgic campaigns on Twitter. The first, called 'Faces of Victory,' celebrates the heroes of the Red Army. The second commemorates important Red Army victories in WWII. Notably, in these tweets, the Red Army is re-imagined as a diverse people's army, a fighting force that represented the diversity of the USSR as its soldiers belonged to different religions, nationalities, and ethnicities. Concurrently, the Russian MFA has used Twitter to lambast Baltic States for re-writing history by ignoring the Red Army's role in the defeat of Nazi Germany (Manor 2019) (Fig. 1).

The third campaign commemorates the flight of Cosmonaut Yuri Gagarin. On Twitter, the MFA re-imagined the Space Race not as a global competition over hegemony, but as an endeavor that advanced all of humanity. The MFA used images from Gagarin's personal life, as well as images from monuments to Gagarin's flight across the world to transform

James Pamment

James.pamment@isk.lu.se

1 Department of Communication, Tel Aviv University, Tel Aviv, Israel

2 Department of Strategic Communication, Lund University, Lund, Sweden the Cosmonaut from as a Russian hero to a global one. In this campaign, Russia celebrated the scientific achievements of the USSR while arguing that the USSR, and the bi-polar system, did not undermine global peace but actually benefitted all of mankind through scientific and technological advancements. ${ }^{1}$

Notably, the Russian MFA's use of nostalgic tropes can be viewed as part of a wider effort to disseminate revisionist narratives that re-interpret history, with an emphasis on WWII. In this way, Russia's use of nostalgic tropes differs from other states' use of nostalgia to narrate complex crisis or reduce feelings of uncertainty following geo-political shifts (e.g., Brexit). Russia's historic revisionism is, in part, a response to a 2019 European Parliament resolution that condemned Russia for colluding with Nazi Germany and starting WWII. The resolution also called for the removal of Soviet war memorials across Europe (Radchenko 2020).

Notably, Russia's historic revisionism, and reliance of nostalgic tropes, may be but a tool to rally domestic support in Putin, while diverting attention from Russia's domestic woes (Sargeant 2021). For example, in a 2020 meeting of world leaders Putin discussed WWII at length, arguing that the war was the result of Poland's collusion with Nazi Germany (Radchenko 2020). Taken within this revisionist context, the Russian MFA's re-imagining of the Red Army and the Space Race is but one element in a larger effort in which a tangled web of official and non-official digital channels promote a a meta-narrative built on a dichotomy of "Russia as an ally with a common history, culture and interests" and the "West as a foreign, imperialist enemy" (Ukraine, Crisis Media Center 2020).

We contend that nostalgia also underpins Russia's attempts to market its Covid19 vaccine on Twitter. The vaccine's very name, Sputnik, harks back to the USSR and the Space Race. The name suggests that the same minds

\footnotetext{
${ }^{1}$ See for example https://twitter.com/RussianEmbassy/status/13784 30054519169032; $\quad$ https://twitter.com/RusEmbUSA/status/13692 99852895674371.
} 
Fig. 1 Reimagining the Red Army. (https://twitter.com/mfa russia/status/136926007183901 9009; (https://twitter.com/mfa_ russia/status/132364106011604 5825)

Fig. 2 A Vaccine for all Mankind. (https://twitter.com/sputn ikvaccine/status/1400873674 530557957)

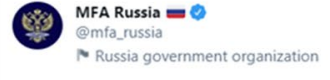

- November 3, 1943, the \#RedArmy launched the Kiev Offensive to free the capital of \#Soviet \#Ukraine from the Nazi invaders. Kiev was liberated by soldiers and officers of diverse ethnic origins. is.gd/9PAZnx \#Kiev \#Victory75 \#WeRemember

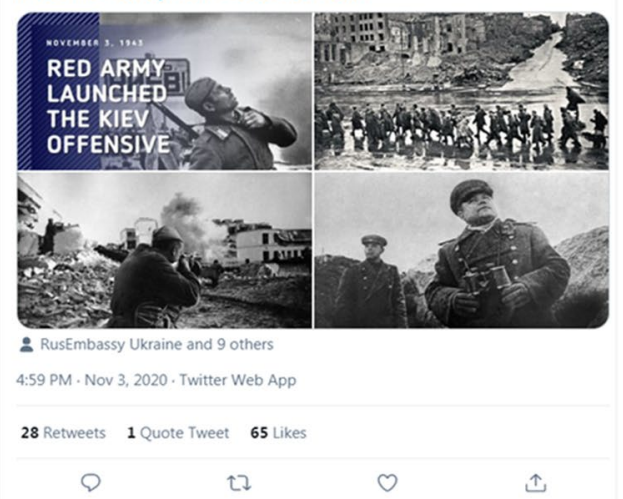

\section{(5)}

BREAKING: Sputnik V announces key international production partners. More than 20 companies in 13 countries will produce enough \#SputnikV to vaccinate $800 \mathrm{mln}$ people per year. RDIF partners are joining the effort to win the fight against \#COVID19. Together we are stronger!

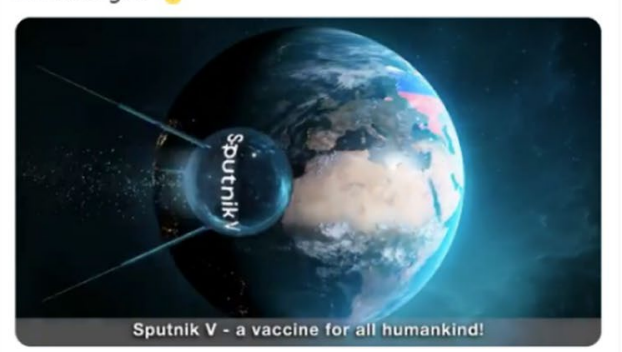

8:54 PM - Jun 4, 2021 - Twitter Media Studio

632 Retweets 66 Quote Tweets 2,100 Likes

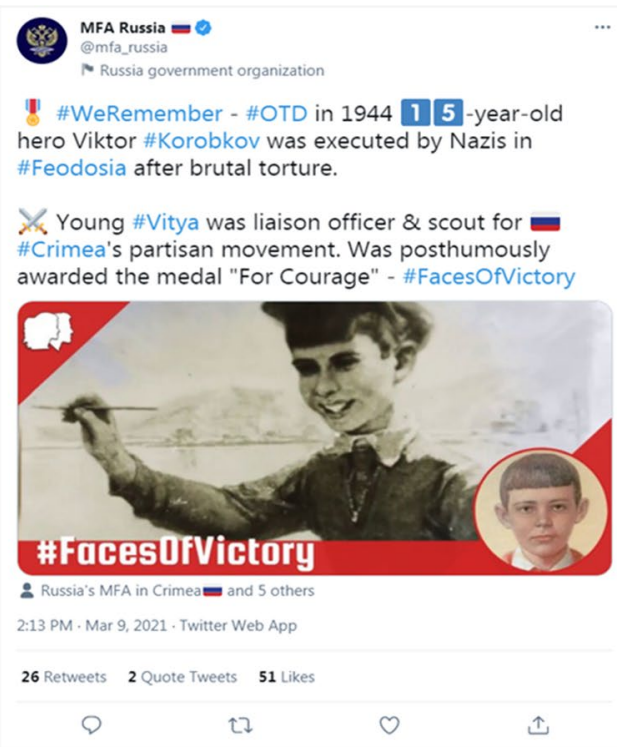

Sputnik Ve

@sputnikvaccine

BREAKING: Sputnik $V$ announces key international production partners. More than 20 companies in 13 countries will produce enough \#Sputnik $V$ to vaccinate $800 \mathrm{mln}$ people per year. RDIF partners are joining the effort to win the fight against \#COVID19. Together we are stronger!

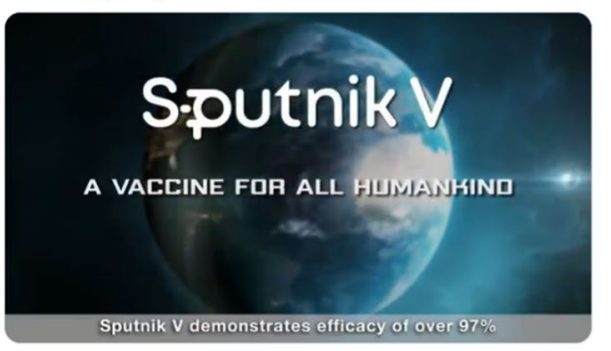

8:54 PM - Jun 4, 2021 . Twitter Media Studio

632 Retweets 66 Quote Tweets 2,100 Likes that launched the first satellite into orbit and that catapulted Gagarin into space produced Russia's Covid19 vaccine.

Notably, Russia is the only country to create a dedicated Twitter account for its vaccine (@SputnikVaccine). Russia has used this account to promote three narratives. First, much like Gagarin, Sputnik is promoted as Russia's gift to humanity. One tweet included images of the Sputnik satellite orbiting Earth followed by the words "Sputnik-A Vaccine for all Humankind." A second tweet suggested that the world thanked Russia for its vaccine development. The images accompanying this particular tweet included nostalgic tropes such as the Kremlin's Red Square and the Red Star associated with the USSR (Figs. 2, 3).

Second, Russia used Twitter to emphasize the efficacy of its vaccine rollout by tweeting images of vaccine deliveries to nations struggling to cope with pandemic such as India,
Iran, and Mexico. ${ }^{2}$ Russia also depicted the local production of the Sputnik vaccine in Argentina, Belarus Egypt, and Iran. It was through local production that the Sputnik vaccine was, in theory at least, made available to some 3 billion people in more than 64 countries. Images shared on Twitter often depicted the vaccination of older populations (Fig. 4).

The reality, however, has been less effective. Many of the package delivered to have been "small, PR-style packages, for instance to 1020 people in Armenia." 3 A lack

\footnotetext{
${ }^{2}$ See for example- https://twitter.com/sputnikvaccine/status/14105 27375092297730; https://twitter.com/sputnikvaccine/status/14051 33060694110210; https://twitter.com/sputnikvaccine/status/14001 04966518345728 .

${ }^{3}$ https://euvsdisinfo.eu/eeas-special-report-update-short-assessment-
} 
Fig. 3 Nostalgic Tropes on the Sputnik Account. (https://twitt er.com/sputnikvaccine/status/ 1403752013863739397)
Sputnik Ve

It's \#RussiaDay2021 aand people from around the world are saying "spasibo" for \#SputnikV, the vaccine for the whole mankind. Together we are stronger! Let's defeat this pandemic together!

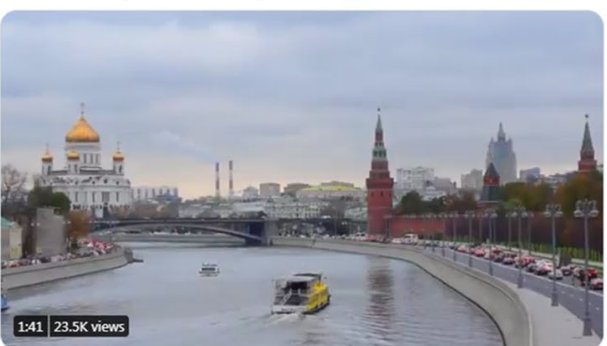

7:32 PM · Jun 12, 2021 · Twitter Web App

234 Retweets 18 Quote Tweets 1,199 Likes
Sputnik V

It's \#RussiaDay2021 aand people from around the world are saying "spasibo" for \#SputnikV, the vaccine for the whole mankind. Together we are stronger! Let's defeat this pandemic together!

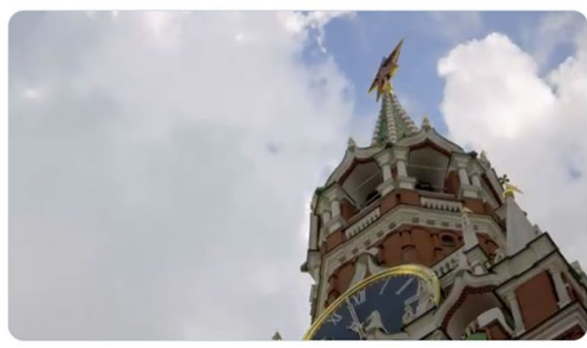

7:32 PM - Jun 12, 2021 - Twitter Web App

234 Retweets 18 Quote Tweets 1,199 Likes
Fig. 4 Administering the Sputnik Vaccine in Argentina and Guatemala. (https://twitter.com/ sputnikvaccine/status/14116 80139356876805; https://twitt er.com/sputnikvaccine/status/ 1403348794692022273 )
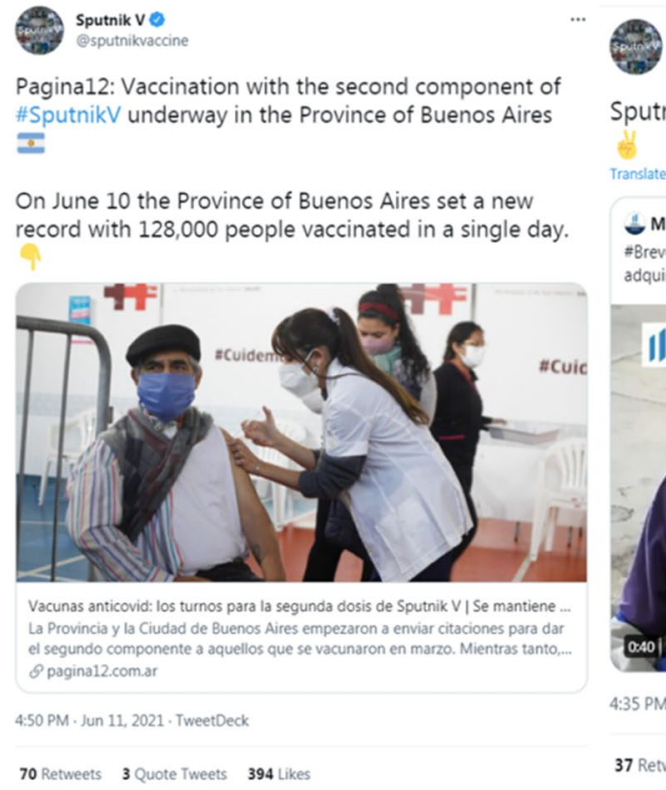

Sputnik V

@sputnikvaccine

Sputnik V vaccination continues in \#Guatemala if

Translate Tweet

\# Ministerio de Salud Pública $@$ MinSaludGuate - Jul 4
\#BrevesMSPAS | El \#MSPAS recibió el lote de 200 mil vacunas \#SputnikV adquiridas por medio de compras directas con el Gobierno Ruso.

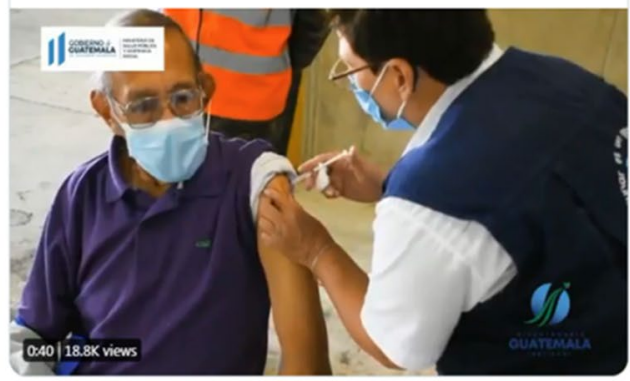

4:35 PM. Jul 4, 2021. Twitter Web App

37 Retweets 5 Quote Tweets 244 likes of production capability in Russia saw production moved abroad in an attempt to meet demand, although delays have hampered outsourcing efforts. During the first half of 2021, many countries claimed that only a fraction of the promised 700 million vaccines, much of which was paid for in advance, had been delivered. For example, Guatemala paid an advance of $\$ 79$ million for 8 million doses, of which 150,000 had arrived by the end of June. Iran received 2

Footnote 3 (continued)

of-narratives-and-disinformation-around-the-covid-19-pandemicupdate-december-2020-april-2021/. million of 60 million ordered, Mexico received 4.1 million of 24 million ordered, and Ghana 40,000 of 3.4 million ordered. $^{4}$

The third narrative argued that Sputnik V was one of the most effective vaccines in the world. To make this claim, Russia referenced prestigious academic publications such as The Lancet or Science confirming the effectiveness of the Sputnik vaccine, or the scientific validity of the Russian approach to vaccine development. Additionally, Russia tweeted reports by media outlets attesting to the vaccine's

\footnotetext{
$\overline{4}$ https://www.bbc.com/news/world-europe-58003893.
} 
Sputnik V

Sputnik $V$ has a high tolerability profile in the population aged $\geq 60$ years in terms of short-term AEFIs, after both doses, a study in EClinicalMedicine journal published by@TheLancet shows

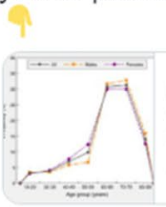

ROCCA observational study: Early results on safety of Sputni... Our results, albeit preliminary, suggest that Sputnik $V$ has a high tolerability profile in the population aged $\geq 60$ years in $\odot$ thelancet.com

1:30 PM - Jul 11, 2021 - TweetDeck

68 Retweets 4 Quote Tweets 256 Likes

Q

$\uparrow$

0

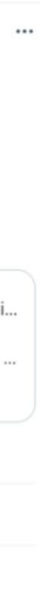

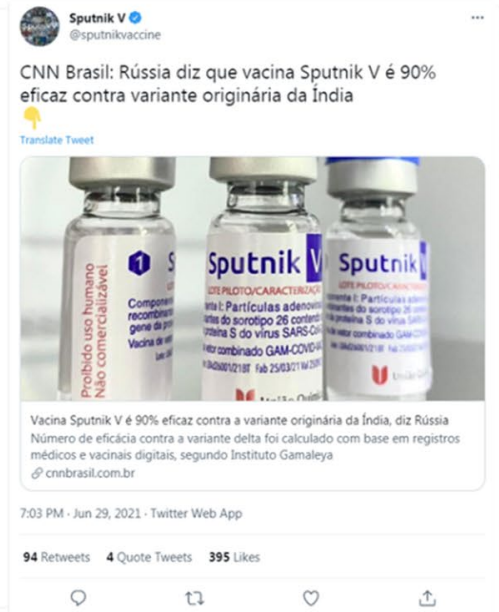

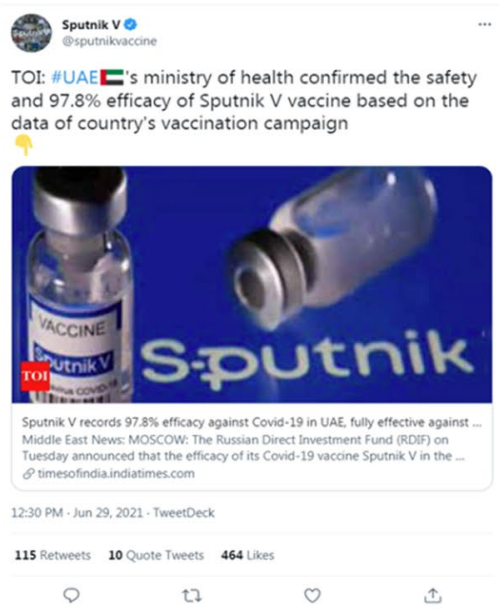

Fig. 5 Sputnik's Scientific Validity. (https://twitter.com/sputnikvaccine/status/1409806346518622208; https://twitter.com/sputnikvaccine/status/ 1414170099271995393; https://twitter.com/sputnikvaccine/status/1409905267286884352)

effectiveness, as well as results from national studies examining the vaccine's efficacy (Fig. 5). ${ }^{5}$

Importantly, one cannot assess Russia's use of the Sputnik Twitter account without examining its use of additional digital accounts to sow mistrust in Western vaccines. We contend that Russia has adopted a two-track communicative strategy and while the Sputnik Twitter account is used to proactively promote Russia's vaccine, a network of official and non-official digital accounts are simultaneously used to discredit other vaccines and lambast the EU and other democracies for mishandling the Covid19 pandemic. Using a vast network of trolls, Bot farms, state-owned media, and fake social media accounts, Russia actively spreads disinformation that undermines trust in Western-made vaccines and Western vaccination programs (EEAS 2021; Sargeant 2021; Gordon and Volz 2021).

Pro-Kremlin outlets have specifically attacked the European Medicine Agency and doubted its impartiality in an attempt to prevent a shared European approach to vaccinating EU citizens. Russia has also berated specific governments arguing that Ukraine's decision not to use the Sputnik vaccine amounts to genocide. Georgia's decision to rely on the EU vaccination program has led to Russian accusations of neo-Western imperialism as Georgia is portrayed as a slave to the EU's will (EEAS 2021).

Russia's promotion of the Sputnik vaccine on Twitter is steeped in nostalgic tropes, ranging from the vaccine's name to visual references to the USSR. The Sputnik account links

\footnotetext{
5 See for example https://twitter.com/sputnikvaccine/status/14037 77078491815936; https://twitter.com/sputnikvaccine/status/14101 56295294947331; https://twitter.com/sputnikvaccine/status/14144

79664702177282 .
}

present day Russia with the USSR and references the Communist ethos of responsibility to the global proletariat. If the Red Army was depicted on Twitter as a people's army, then the Sputnik vaccine is portrayed as the 'people's vaccine,' one available to every citizen around the world. Russia's digital activities surrounding the Covid19 pandemic are therefore of a similar ilk to its historic revisionism of WWII. In both cases, Russia relies on nostalgia to create a moral dichotomy that depicts Russia as a familiar and benevolent friend and the West as an Imperialist enemy.

There was one narrative that was clearly missing from the Sputnik account - the administration of vaccine to Russian citizens. Clearly, domestic failings in the handling both of the pandemic and the vaccine rollout have been glossed over. According to polls, some $60 \%$ of Russians are vaccine sceptics. The absence of such tweets is instructive as Russia may have sought to create a second moral dichotomy between Western countries (e.g., US, UK) that hoard vaccines and seek only to vaccinate their citizens, and Russia that is dedicated to vaccinating the world.

The question that now comes to the fore is how does the Sputnik Twitter account contribute to Russia's public diplomacy efforts? Here we offer three answers. First, Russia used the Sputnik account to juxtapose Russian and Western values. By labeling the vaccine as Russia's gift to humanity, and undermining Western vaccine programs, Russia manifested positive norms and values, chiefly a regard for the wellbeing of all nations and all people. Morality is a crucial component of public diplomacy as morality breeds legitimacy on the international stage. Nations that are seen as promoting positive norms and values may find it easier to advance their foreign policy goals and form alliances in multi-lateral settings (Quelch and Jocz 2009; Van Ham 2014; Manor 2019). 
Second, following the illegal annexation of Crimea, and the digital interventions in the Brexit referendum and the 2016 US elections, Russia suffered from a crisis of credibility. By emphasizing the scientific achievements of the Sputnik V vaccine, and its association with the scientific legacy of the USSR, Russia had some positive news to share, and may have sought to restore some of its lost credibility. According to the Sputnik Twitter account, Russia no longer deals in disinformation or fake news but in verifiable and credible science.

Third, and perhaps most importantly, Russia used Twitter to simultaneously market its vaccine while sowing seeds of discord among EU member states and undermining trust in Western vaccine programs. This is part and parcel of Russia's strategic goals of destabilizing the EU and reducing trust in democratic processes in Western nations. The Sputnik account is thus a prime example of Russia's use of digitally-driven public diplomacy campaigns to obtain offline policy goals.

\section{Declarations}

Conflict of interest On behalf of all authors, no conflict of interests exists.

\section{References}

EEAS Special Report Update: Short Assessment of Narratives and Disinformation Around the Covid-19 Pandemic. 2021. EU VS Disinfo. https://euvsdisinfo.eu/eeas-special-report-update-shortassessment-of-narratives-and-disinformation-around-the-covid19-pandemic-update-december-2020-april-2021/.

Gordon, M. R., and D. Volz. 2021. Russian Disinformation Campaign Aims to Undermine Confidence in Pfizer, Other Covid-19 Vaccines, U.S. Officials Say. Wall Street Journal. https://www.wsj. com/articles/russian-disinformation-campaign-aims-to-under mine-confidence-in-pfizer-other-covid-19-vaccines-u-s-officialssay-11615129200.

Hybrid Warfare Analytical Group. 2020. Russian Revisionism in Ukraine: Overview and Recommendations. Ukraine Crisis Media Center. https://uacrisis.org/en/russian-revisionism-in-ukraineoverview-and-recommendations.

Manor, Ilan. 2019. The digitalization of public diplomacy. New York: Springer International Publishing.

Miskimmon, Alister, Ben O'loughlin, and Laura Roselle. 2014. Strategic narratives: Communication power and the new world order. London: Routledge.

Quelch, John A., and Katherine E. Jocz. 2009. Can brand Obama rescue brand America? The Brown Journal of World Affairs 16 (1): 163-178.

Radchenko, S. 2020. Vladimir Putin Wants to Rewrite the History of World War II. Foreign Policy. https://foreignpolicy.com/2020/01/ 21/vladimir-putin-wants-to-rewrite-the-history-of-world-war-ii/.

Sargeant, M. L. 2021. Russia's Hybrid War in Ukraine: Historical Revisionism and 'Twiplomacy.' Small Wars Journal. https:// smallwarsjournal.com/jrnl/art/russias-hybrid-war-ukraine-histo rical-revisionism-and-twiplomacy.

Saunders, R. 2020. Brexit and Empire: 'Global Britain 'and the myth of imperial nostalgia. The Journal of Imperial and Commonwealth History 48 (6): 1140-1174.

Surowiec, Paweł, and Ilan Manor, eds. 2021P. Public diplomacy and the politics of uncertainty. London: Palgrave Macmillan.

Van Ham, Peter. 2014. Social power in public diplomacy. In Relational, networked and collaborative approaches to public diplomacy, ed. R.S. Zaharna, A. Arsenault, and A. Fisher, 31-42. London: Routledge.

Publisher's Note Springer Nature remains neutral with regard to jurisdictional claims in published maps and institutional affiliations.

Ilan Manor is a digital diplomacy scholar at the Tel Aviv University and a member of Oxford University's Digital Diplomacy Research Group.

James Pamment, Ph.D., is associate professor of Strategic Communication at Lund University and co-editor-in-chief of the Place Branding and Public Diplomacy journal. 